Sani Kunac, asist.

Filozofski fakultet Sveučilišta u Splitu

Odsjek za pedagogiju

skunac@ffst.hr

\title{
ODGOJNO-OBRAZOVNE FILOZOFIJE - KLJUČ RAZUMIJEVANJA ULOGE NASTAVNIKOVIH UVJERENJA U ODGOJNO-OBRAZOVNOJ PRAKSI
}

Sažetak: Suvremena je paradigma u pedagogiji usmjerena na holistički razvoj pojedinaca kurikulnim pristupom s naglaskom na ishode učenja i poučavanja. Naglašava se aktivna uloga učenika u nastavi, ali $i$ važnost uloge nastavnika kao osobe koja oblikuje nastavno okruženje i organizira nastavni proces. Odgojno-obrazovne filozofije nastavnikā i uvjerenja koja su im u pozadini uvelike utječu na njihovu odgojno-obrazovnu praksu i djelovanje u nastavi. No još uvijek postoji neujednačenost u definiranju, identifikaciji i klasifikaciji odgojno-obrazovnih filozofija. Cilj je ovoga rada dati pregled literature o odgojno-obrazovnim filozofijama, pridonijeti određenju konstrukta, uputiti na važnost istraživanja odgojno-obrazovnih filozofija unutar pedagogije te uputiti na povezanost između odgojno-obrazovnih filozofija nastavnika i različitih vidova njihova odgojno-obrazovnog djelovanja.

Ključne riječi: nastava, suvremene odgojno-obrazovne filozofije, tradicionalne odgojno-obrazovne filozofije

\section{UVOD}

Nastavnici su, uz učenike, glavni subjekti odgojno-obrazovnog procesa. Njihova je uloga, među ostalim, oživotvorenje kurikula u razredu. Pogotovo danas kada su u Republici Hrvatskoj (RH) na snazi novi predmetni kurikuli (Ministarstvo znanosti i obrazovanja, 2019) u kojima su istaknuti ishodi učenja koji trebaju biti ostvareni, a nastavnici imaju slobodu u osmišljavanju nastave koja će voditi prema ostvarenju tih ishoda učenja. Različiti su pristupi kojima se mogu voditi u planiranju i realizaciji nastavnoga procesa kako bi došli do ostvarenja željenih ishoda. No što je to što utječe na pristup nastavi svakoga pojedinog nastavnika? Jesu li to službeni dokumenti nastali pod utjecajem trenutačne odgojno-obrazovne politike? Njihova znanja? Stavovi? Kompetencije? Iskustva? Sve navedeno? Ili pak nešto dublje što nam je golim okom nevidljivo i što je teže zahvatiti? 
Danas smo u istraživanjima uglavnom više orijentirani na ono „opipljivo“ i vidljivo, na mjerenje ostvarenosti ishoda učenja, razvijenosti kompetencija, upotrebu nastavnih metoda, strategija, oblika rada, a s druge strane pomalo zanemarujemo ono „nevidljivo“ što daje smisao svemu vidljivome i što je njegov temelj. To se odnosi na uvjerenja i vrijednosti koji bitno utječu na praksu, tj. na sastavnice skrivena kurikula. No to je tema koja nije do kraja iscrpljena, a ključna je za pedagogiju jer upravo nastavnikova uvjerenja i odgojno-obrazovne filozofije uvelike utječu na nastavu te pokušaj bilo kakve promjene i reforme odgoja i obrazovanja neće uspjeti ako nismo uistinu toga svjesni. Nastavnici odbijaju u razredu raditi ono u što ne vjeruju ili s čim se ne slažu, premda se katkada „na papiru“ doima kao da rade onako kako to odgojno-obrazovna politika i službeni dokumenti od njih zahtijevaju. Potrebno je stoga vratiti se izučavanju nastavničkih uvjerenja i odgojno-obrazovnih filozofija te njihova utjecaja na odgojno-obrazovnu praksu kako bismo uistinu došli do potpunijeg razumijevanja njihove povezanosti i osmislili načine kako ih uskladiti s mogućim reformskim pokušajima da bi oni bili uspješni. Pregledom literature iz odabranog područja ovaj rad daje odgovor na gore navedena pitanja o tome što utječe na nastavnikov pristup nastavi. Cilj je rada, stoga, pružiti uvid u literaturu o nastavničkim odgojno-obrazovnim filozofijama, dati prilog u određenju tog konstrukta i uputiti na važnost njegova istraživanja unutar pedagogije te povezati nastavničke odgojno-obrazovne filozofije s njihovim djelovanjem u odgojno-obrazovnoj praksi.

\section{ODREĐENJE OSNOVNIH KONSTRUKATA}

\section{A) ODGOJNO-OBRAZOVNE FILOZOFIJE}

Riječ filozofija korijen ima u dvjema grčkim riječima: philo (ljubav) i sophos (mudrost), pa je doslovno možemo prevesti kao ljubav prema mudrosti. Bavi se brojnim pitanjima, a među ostalim i pitanjima o prirodi ljudske spoznaje, što je to znanje i kako dolazimo do njega, pitanjima vrijednosti itd. Pripadnici različitih pristupa u filozofiji različito će odgovoriti na ova pitanja, isto kao i nastavnici. Upravo zbog tih razlika javljaju se i različite odgojno-obrazovne filozofije koje imaju različita promišljanja o ulozi nastavnika, ulozi učenika, ciljevima i smislu školovanja i prirodi kurikula. Odgojno-obrazovne filozofije $e^{1}$ utemeljene su u određenim uvjerenjima koja se tiču prethodno navedenih pitanja.

Autori različito pristupaju određenju konstrukta odgojno-obrazovnih filozofija, a velik je broj radova koji i ne nude eksplicitnu definiciju, nego pišu o njima kao da se već podrazumijeva na što se oni odnose. Velik broj autora slaže se međutim

${ }^{1}$ Odgojno-obrazovne filozofije razlikuju se od pojmova filozofija odgoja i filozofija odgoja i obrazovanja, koji se u pedagogijskoj teoriji učestalo rabe. Filozofija odgoja (odgoja i obrazovanja) odnosi se na disciplinu unutar filozofije koja se bavi proučavanjem odgoja i obrazovanja s aspekta filozofije, dok se pojam odgojno-obrazovna filozofija odnosi na uvjerenja nastavnika o pitanjima koja se tiču odgoja i obrazovanja. 
sa stajalištem da su uvjerenja nastavnika o odgoju i obrazovanju oblikovana odgojno-obrazovnim filozofijama koje nastavnici prihvaćaju (Gezer, 2018; Ilhan i sur., 2014; Pajares, 1992). Beatty i sur. (2009, str. 100) daju sljedeću definiciju: „Odgojno-obrazovna filozofija je narativni opis pojedinčeve koncepcije podučavanja, uključujući i objašnjenje za odabir nastavnih metoda." Cetinić (2005) ističe da su odgojno-obrazovne filozofije utemeljene u uvjerenjima o vrijednostima, o učenju i podučavanju, o efikasnosti nastavnika te $u$ epistemološkim uvjerenjima nastavnika - o prirodi znanja i učenja. One su osobne i predstavljaju refleksiju identiteta pojedinačnog učitelja, no isto tako sadrže i neke dijeljene temelje, a s obzirom na to da se o njima rijetko govori u svakodnevnoj praksi, one se implicitno dijele (Beatty i sur., 2009; Watson i Coso Strong, 2013; Williams, 1996). Pojedinci često nisu svjesni svojih odgojno-obrazovnih filozofija i vrlo je vjerojatno da ih ne bi ni mogli ni znali imenovati, već se one češće pojavljuju na implicitnoj razini. Osim toga, odgojno-obrazovne filozofije značajne su u određivanju odgojno-obrazovnih ciljeva i u oblikovanju cjelovite odgojno-obrazovne perspektive, kako pojedinca, tako i obrazovne politike i kurikula, te daju nastavnicima temelj i određenu strukturu za organizaciju nastavnog procesa (Baş, 2015; Gezer, 2018; Ornstein i Hunhins, 2018). S tim se slaže i Cetinić (2005) te ističe da odgojno-obrazovne filozofije nastavnika, koje uvjetuju njihova uvjerenja, utječu na sve faze njihova djelovanja u nastavi - od pripremanja, planiranja, ostvarivanja do vrjednovanja nastave.

Uočavamo da su odgojno-obrazovne filozofije širi pojam od uvjerenja, one $u$ sebi objedinjuju metafizička, epistemološka i aksiološka uvjerenja nastavnika koja zajedno čine određenu odgojno-obrazovnu filozofiju koju možemo imenovati. Slijedom navedenoga, moguće je ponuditi definiciju konstrukta - odgojno-obrazovne filozofije ${ }^{2}$ predstavljaju poimanja nastavnika o pitanjima koja su usko vezana za odgoj i obrazovanje, a zasnovana su na njihovim metafizičkim, epistemološkim i aksiološkim uvjerenjima.

Beatty i sur. (2009) također ističu da se nastavnici suočavaju s pitanjima o prirodi znanja, odgoju i obrazovanju, nastavi i metodama koje su prikladne za uspješnu nastavu te na njih pokušavaju dati odgovor, a taj je odgovor utemeljen u njihovim uvjerenjima - metafizičkim, epistemološkim i aksiološkim. Metafizika ispituje prirodu stvarnosti i pokušava odgovoriti na pitanje „Što je stvarno?“. Odgovor na to pitanje može biti da je stvarnost objektivna ili pak da je subjektivna i socijalno konstruirana. Filozofije pragmatizma, egzistencijalizma i kritičke teorije drže da je stvarnost subjektivna, dok s druge strane metafizika realizma i idealizma drže da je objektivna. Epistemologija pak traži odgovor na pitanje „Kako znamo ono što znamo?“. Beatty i sur. (2009), pozivajući se na Hessonga i Weeksa (1991), prikazuju pet različitih odgovora na to pitanje: a) otkrivenjem od Boga, b) autoritetom

${ }^{2}$ Poimanje se definira kao ,duhovna djelatnost kojom se misli bit nekog stvarnog ili zamišljenog predmeta, v. shvaćanje.“(Udruga za promicanje filozofije Filozofija.org, https://www.filozofija.org/rjecnik-filozofskih-pojmova/) 
stručnjaka, c) rasuđivanjem pojedinca, d) pojedinčevom osjetilnom percepcijom i e) pojedinčevom intuicijom. Uvjerenja o prirodi znanja značajno utječu na nastavnikove pristupe poučavanju, na metode rada koje odabiru, načine na koje ispituju znanje učenika itd. Aksiologija pokušava odgovoriti na pitanje , Što je vrijedno kao kriterij za prosudbu?", bavi se pitanjima vrijednosti, a te vrijednosti se nalaze na dva pola - jedan se odnosi na racionalnost, univerzalni kriterij i autonomiju individue, a drugi na kontekstualnost, neuniverzalnost i relacionalnost. Sva navedena uvjerenja uvelike su povezana s odgojno-obrazovnim filozofijama, a posljedično i s pristupima poučavanju svakoga nastavnika. Isti autori (2009) identificiraju pet pristupa u filozofiji koji imaju znatan utjecaj na odgojno-obrazovne filozofije: a) idealizam, b) realizam, c) pragmatizam, d) egzistencijalizam i d) kritičku teoriju. Metafizička, epistemološka i aksiološka uvjerenja koja su u pozadini navedenih pristupa u filozofiji u pozadini su i odgojno-obrazovnih filozofija.

\section{B) UVJERENJA U ODGOJU I OBRAZOVANJU}

Djelovanje pojedinaca u svim područjima njihova života pod snažnim je utjecajem njihovih uvjerenja o različitim pitanjima i aspektima života, pa tako uvjerenja utječu i na djelovanja nastavnika u odgojno-obrazovnom procesu. Početna istraživanja uvjerenja nastavnika istraživala su se uglavnom iz područja psihologije odgoja i obrazovanja te u područjima matematike i prirodoznanstvene skupine predmeta, materinskoga jezika i povijesti (Skott, 2015). Danas se uvjerenja nastavnika istražuju i unutar pedagogije, počevši od istraživanja uvjerenja odgojitelja u predškolskim ustanovama pa sve do istraživanja uvjerenja nastavnika u obrazovanju odraslih.

Uvjerenja su pak konstrukt koji nije jednostavno zahvatiti i za koji još uvijek ne postoji dogovor o jednoj prihvaćenoj eksplicitnoj definiciji. Upravo zbog toga često dolazi i do metodoloških problema u zahvaćanju ovoga konstrukta istraživanjima (Skott, 2015). Pratt i sur. (2016) uvjerenja definiraju kao najapstraktniji i najnedostupniji te najmanje fleksibilan aspekt koji utječe na poučavanje nastavnika. Razlog je taj što svaki nastavnik implicitno posjeduje određena uvjerenja o učenju, znanju, poučavanju i o ulozi nastavnika, ali malo njih svjesno razmišlja o svojim uvjerenjima ili ih imenuje, te ih nastavnici često nisu niti potpuno svjesni.

Taylor i sur. (2001) uvjerenja definiraju kao deklarativne tvrdnje o tome što se pretpostavlja da je istinito, tj. dobro ili ispravno u odnosu na učenje i poučavanje. Ističu da su ona izrečena sa sigurnošću i često korištena kako bi se opravdali temeljno znanje ili neformalna teorija poučavanja. Slično navodi i Dunkin (2002, str. 42) koji kaže da uvjerenja predstavljaju ,sud nastavnikā o uspješnosti poučavanja kao intervencije, njihove procjene o osobnom utjecaju na učenje učenika, njihova uvjerenja o tome u kojoj mjeri posjeduju nastavničke kompetencije, kao i kriterij po kojem evaluiraju svoje poučavanje i sebe kao nastavnike." Pojedinčeva uvjerenja razlikuju se u pogledu jasnoće, pouzdanosti i mjesta koje zauzimaju; 
neka su nedovoljno jasna (maglovita) i implicitna, druga su potpuno jasna i lako ih je objasniti, neka su marginalna za pojedinca, a druga središnja ili dominantna (Pratt i sur., 2016). S navedenim se slaže i Richardson (2003, prema Skott, 2015) te dodaje da pojedinac iznimno teško mijenja svoja dominantna uvjerenja, dok su marginalna podložnija promjenama.

Uz poučavanje su usko vezana uvjerenja o znanju, tj. pojedinčeve osobne epistemologije. Dva su dijametralno suprotna pogleda na znanje - objektivizam i subjektivizam. Objektivizam promatra znanje kao nešto što postoji izvan onoga koji uči i što je utemeljeno u logici otkrivanja, a subjektivizam smatra da je znanje nešto osobno, društveno i kontekstualno, konstruirano od osobe koja uči, a utemeljeno je u logici interpretacije. Dva navedena pogleda najbolje je promatrati na kontinuumu jer ne prihvaćaju svi pojedinci ni potpuno objektivistička ni potpuno subjektivistička uvjerenja o znanju (Pratt i sur., 2016).

Osamdesetih godina 20. stoljeća uvjerenja su u području proučavanja odgoja i obrazovanja došla u prvi plan jer su se istraživanja počela sve više usmjeravati na razumijevanje čina poučavanja iz perspektive nastavnika (Nespor, 1987). Istraživači su došli do zaključka da prvo trebamo razumjeti uvjerenja kojima nastavnici definiraju svoje djelovanje, kako bismo uistinu razumjeli čin poučavanja. Sve se više počelo uviđati da ne možemo potpuno razumjeti čin poučavanja ako se usredotočimo samo na ono što vidimo - na strategije učenja i poučavanja, na nastave metode koje se primjenjuju, na oblike rada itd. Samo vidljivi aspekt nastave ne omogućuje nam da u potpunosti razumijemo što je to utjecalo na pojedine izbore u pripremi, organizaciji i izvedbi nastave. Ne možemo prema tome potpuno razumjeti sam čin poučavanja i sve što na njega utječe dok u istraživanjima ne zahvatimo uvjerenja nastavnika o različitim aspektima odgoja i obrazovanja.

Rissanen i sur. (2016) u svojem se radu pozivaju na Dweck $(2000,2006)$ i teoriju o načinima razmišljanja koja se bavi implicitnim uvjerenjima što ih pojedinac ima o osnovnim ljudskim kvalitetama. Po toj teoriji dva su implicitna uvjerenja koja pojedinac može posjedovati: 1) inkrementalna (razvojna) teorija - oni koji je posjeduju vjeruju da su inteligencija, osobnost i sposobnosti nešto što se može razvijati i na što je moguće utjecati; 2) teorija entiteta (fundamentalna) - osnovne su kvalitete statične i nepromjenjive, to je jednostavno nešto s čim se rodimo. Isti su autori (2016) metodom studije slučaja došli do spoznaje da nastavnikove implicitne teorije mogu utjecati na pedagoško razmišljanje nastavnika te su opisali moguće mehanizme u povezivanju načina razmišljanja nastavnika s njihovom pedagoškom praksom. Nastavnikova uvjerenja utjecala su na razumijevanje učenja, poučavanja, studiranja i na samu motivaciju. Osoba s dominantno inkrementalnom teorijom bila je više usmjerena na proces i na poučavanje u skladu sa sposobnostima učenika te na pravedno vrjednovanje njihovih postignuća. Smatrala je da su emocionalni procesi i strategije učenja najveći prediktori učenja i postignuća, stoga su njezine namjere u poučavanju bile pružiti emocionalnu potporu i 
pomoći učenicima da pronađu prikladne metode učenja. Atmosfera u razredu bila je orijentirana na uspješnost, a stalno su naglašavani napredak i učenje. Nedostatak motivacije vidjela je u prethodnim neuspjesima učenika, lošim tehnikama učenja i u nedovoljnom trudu. Osoba s dominantnom teorijom entiteta bila je više usmjerena na osobne, nepromjenjive karakteristike učenika te ih je često opisivala njihovim postignućima ili talentima, svoj uspjeh mjerila je napretkom učenika u smislu pomaganja da dobiju ocjene koje odgovaraju njihovim kvalitetama. Nedostatak motivacije ta je osoba objašnjavala niskim sposobnostima učenika, a atmosfera u razredu bila je orijentirana na izvedbu, evaluaciju i postignuća, pri čemu se često razgovaralo o ocjenama. Autori su došli do zaključka da pojedinci imaju snažnu potrebu za dokazivanjem svoje implicitne teorije - nastavnik koji je zastupao teoriju entiteta više je uživao i trudio se u radu s uspješnim učenicima, dok je nastavnica koja je zastupala inkrementalnu teoriju više uživala i trudila se u radu s neuspješnijim učenicima.

Vezu između nastavnikovih uvjerenja i djelovanja, tj. nastavne prakse, uočava više autora (Hativa i Goodyear, 2002; Nespor, 1987; Pajares, 1992; Pratt i sur., 2016; Rissanen i sur., 2016; Skott, 2015). Analizom prethodnih istraživanja i znanstvenih radova Pajares (1992) primjećuje povezanost između uvjerenja koja pojedinac ima i njegova ponašanja te ističe da su uvjerenja koja pojedinci posjeduju dobri indikatori za odluke koje donose u svojem životu. Konkretno, uvjerenja nastavnika utječu na njihovu percepciju, na odluke i sudove koje donose, a koji potom utječu na njihovo ponašanje na nastavi. Hativa i Goodyear (2002) naglašavaju da nastavnikove teorije o poučavanju, učenju i učenicima snažno utječu na nastavnikove ciljeve u poučavanju i na ponašanje nastavnika u nastavi. Na temelju analize dostupne literature zaključuju da su dotadašnja istraživanja pokazala povezanost između nastavnikova mišljenja, uvjerenja i znanja, nastavne prakse nastavnika i učenja učenika. Stoga upozoravaju da se veća pozornost treba posvetiti proučavanju veze između ponašanja i uvjerenja nastavnika.

Skott (2015) ističe da se nastavnikova uvjerenja promatraju kao načela koja objašnjavaju praksu. Uspješnost nečijeg djelovanja ne možemo prosuđivati samo na osnovi onoga što vidimo, potrebno je razumjeti pojedinčeve namjere (ono što pojedinac želi postići) i razloge zbog kojih pojedinci misle da je to bitno i korisno, tj. njihova uvjerenja. Bez toga nećemo uspjeti u potpunosti razumjeti sam čin poučavanja. Isti je autor (2015) pregledom literature o uvjerenjima u odgoju i obrazovanju primijetio da je velik dio ranih istraživanja o uvjerenjima nastavnika bio utemeljen na očekivanoj jednodimenzionalnoj povezanosti između ponašanja nastavnika i učenja učenika te se potom istraživački interes pomicao s vidljiva ponašanja na svrhovito i promišljeno djelovanje i na očekivane uzroke tih djelovanja u smislu uvjerenja nastavnika. Smatralo se da su uvjerenja glavna odrednica aktivnosti nastavnika i posljedično učenja učenika. Istraživanja o uvjerenjima nastavnika, s druge strane, isticala su i važnost istraživanja promišljanja nastavnika, no 
ponajprije su u njima vidjela prepreku i nešto što je potrebno promijeniti jer uvjerenja nastavnika često nisu u skladu s uvjerenjima koja su u pozadini dominantne odgojno-obrazovne politike te stoga pokušaji bilo koje reforme često ne završe uspješno jer ih nastavnici ne prihvaćaju. Autor naglašava da se u brojnim istraživanjima ističe značaj nastavnikovih uvjerenja koji ona imaju za uspjeh obrazovnih reforma jer uvjerenja, ako nisu u skladu s vrijednostima koje zastupa reforma, mogu potkopavati njezin uspjeh. Pa čak i tada kada nastavnici uvedu promjene $u$ svoj rad, da zadovolje inicijative reforme, to može biti samo površinski i ogledati se u metodama i oblicima rada koji su trenutačno ,poželjni“, no njihova se prava svrha ne ostvaruje jer se nastavnik i dalje služi tim, možda drukčijim metodama i oblicima rada da ostvari ciljeve koje on ima, a koji su u skladu s uvjerenjima što ih zastupa (Spillane i sur., 2002, prema Skott, 2015).

Da bi odgojno-obrazovne reforme ili bilo koje promjene uistinu bile uspješne, uvjerenja koja su u pozadini odgojno-obrazovnih filozofija tih reforma trebaju biti u skladu s odgojno-obrazovnim filozofijama učitelja i nastavnika. To možemo postići, ili se tomu barem možemo približiti, ako u stručnim usavršavanjima koja se organiziraju za nastavnike s ciljem uvođenja promjena koje su u skladu s reformom organiziramo, među ostalim, i predavanja i radionice kojima će biti cilj osvještavanje odgojno-obrazovnih filozofija nastavnika, kao i uvjerenja koja su u pozadini odgojno-obrazovne filozofije kojom se vodi reformska inicijativa.

\section{ODNOS ODGOJNO-OBRAZOVNIH FILOZOFIJA I DJELOVANJA NASTAVNIKA}

Odgojno-obrazovne filozofije ključ su razumijevanja nastavnikova djelovanja i uloge nastavnikovih uvjerenja u odgojno-obrazovnoj praksi. One omogućuju nastavnicima da s holističkog motrišta sagledavaju i povezuju odgojno-obrazovne teorije i praksu (Erden, 1998, prema Ilhan i sur., 2014), utječu na implementaciju različitih aktivnosti učenja i poučavanja, na međusobne interakcije u razredu (Baş, 2015) te na spremnost nastavnika na prihvaćanje reformā (Trigwell i sur., 1996, prema Gezer, 2018).

Preko odgojno-obrazovnih filozofija nastavnici mogu obuhvatnije razumijevati odgojno-obrazovni proces i definirati sebe kao nastavnike. Şahan i Terzi (2015) primarnu ulogu učitelja vide u oblikovanju pojedinaca i društva, a učitelji to mogu postići oslanjanjem na odgojno-obrazovne filozofije koje zastupaju i na 
pristupe učenju i poučavanju ${ }^{3}$ koji odgovaraju njihovim odgojno-obrazovnim filozofijama. Postavku da učitelji oblikuju pojedinca i društvo možemo dovesti u pitanje jer iz suvremene pedagogijske perspektive učitelji nemaju ni moć, a ni zadatak oblikovati pojedince. Oni bi učenicima trebali biti podrška u cjelokupnom razvoju (kognitivnom, afektivnom i psihomotoričkom), trebali bi se oslanjati na njihove dispozicije, osmišljavati poticajnu nastavu i voditi ih prema ostvarenju ishoda učenja, a način na koji to učitelji ostvaruju pod utjecajem je njihovih odgojno-obrazovnih filozofija.

Brojni autori uočavaju da su djelovanja nastavnika pod snažnim utjecajem njihovih odgojno-obrazovnih filozofija (Cetinić, 2005; Gezer, 2018; Ilhan i sur., 2014; Ornstein i Hunhins, 2018; Şahan i Terzi, 2015; Watson i Coso Strong, 2013; Williams, 1996) te su one ključne za uvođenje promjena u odgoju i obrazovanju (Baş, 2015; Ornstein i Hunhins, 2018). S navedenim se slažu Terzi i Uyangör (2017), koji uočavaju i to da je svaki odgojno-obrazovni sustav, a time i odgojno-obrazovna politika s pripadnim dokumentima vezanima za odgoj i obrazovanje, pod utjecajem neke odgojno-obrazovne filozofije ili filozofijā (premda uglavnom to nigdje nije izrijekom navedeno). Tako se i različiti pristupi u pedagogiji i pedagogijske koncepcije oslanjaju i oslanjali su se na neke osnovne filozofske ideje i pravce te na njihova shvaćanja čovjeka i svijeta. Beatty i sur. (2009) iznose zaključke više autora da ono u što vjerujemo, naša uvjerenja o učenicima, nastavnim materijalima i svemu ostalome što je značajno za nastavni proces, značajno utječe na način na koji mi djelujemo u razredu, neovisno o sadržaju koji poučavamo i našem stilu poučavanja. Odgojno-obrazovne filozofije mogu otkriti dublje strukture i vrijednosti koje daju značenje i opravdanje pojedinčevu pristupu poučavanju. Kada razumijemo odgojno-obrazovne filozofije nastavnika, također ističu, to nam omogućuje da stavimo nastavne prakse pojedinaca u kontekst šire zajednice i tako dobijemo obuhvatniji pogled na fenomen. Osim toga, možemo ih promatrati i kao alat za nastavnikovo osobno usavršavanje procesom refleksije. Mcalpine i Weston (2002) te Entwistle i Walker (2002) smatraju da je poboljšanje poučavanja razvojan proces koji uključuje promjenu uvjerenja i koncepcija o poučavanju, učenju i učenicima, a to je moguće postići procesima refleksije i samorefleksije.

Williams (1996) uočava da nastavnici često nisu svjesni vlastitih uvjerenja i odgojno-obrazovnih filozofija ni njihova utjecaja na nastavnu praksu, a moći će ih preispitati i mijenjati tek kada postanu osviješteni o vlastitim uvjerenjima. Kod

\footnotetext{
${ }^{3}$ Pristupi poučavanju mogu se promatrati s dvaju aspekata: a) oni reflektiraju ponašanje tijekom poučavanja koje je nastavnicima najprihvatljivije, a u tom slučaju usko su povezani s nastavnikovim koncepcijama poučavanja (Kember i Kwan, 2000, prema Norton i sur., 2005); b) pristupi poučavanju reflektiraju ponašanje koje je nastavnik prinuđen prihvatiti zbog kurikula, institucije ili studenata. U tom je slučaju pojam povezaniji s nastavnikovom percepcijom sredine za poučavanje nego s nastavnikovim koncepcijama poučavanja u učionici (Martin i sur. 2000, prema Norton i sur., 2005). Više autora (Åkerlind, 2004, 2008; Martin i sur., 2002; Norton i sur., 2005) ističe da se dvije dimenzije u nastavnikovim koncepcijama i pristupima poučavanju i učenju uvijek uočavaju, a to su usmjerenost na nastavnika i usmjerenost na studenta.
} 
uspješnih i efikasnih učitelja njihove odgojno-obrazovne filozofije u skladu su s njihovom praksom (Clarkson, 1983; Clandinin, 1986; Hart, 1990, prema Williams, 1996). Procesom refleksije o svojim odgojno-obrazovnim filozofijama postajemo svjesniji svojih uvjerenja. Poznavanjem (eksplicitnim) odgojno-obrazovnih filozofija, tj. osvještavanjem uvjerenja koja su im u podlozi, moguće je uočiti dijelove nastavne prakse koji nisu u skladu s njima pa na osnovi toga refleksijom utvrditi je li potrebno mijenjati dijelove nastavne prakse ili svoju odgojno-obrazovnu filozofiju. To tada postaje alat za stvaranje i održavanje jasnog i autentičnog nastavničkog identiteta (Beatty i sur., 2009). Isti autori također ističu važnost procesa refleksije i javnog govora o odgojno-obrazovnim filozofijama jer se tako omogućuje pronalaženje dodirnih točaka među nastavnicima, ali i uočavanje razlika među njima. Rasprava o odgojno-obrazovnim filozofijama mora biti otvorena (za nova iskustva i poglede), ispunjena poštovanjem prema različitostima, a ne usmjerena na kritiku. To je bitno zbog toga što su odgojno-obrazovne filozofije značajna, ako ne i temeljna sastavnica pojedinca kao nastavnika, njegova identiteta, pa izravnim kritiziranjem možemo nehotice povrijediti onoga komu je takva kritika upućena, koji će se potom vrlo vjerojatno zatvoriti što će onemogućiti bilo kakav nastavak razgovora o toj temi.

Radom na sebi i na osvještavanju svojih odgojno-obrazovnih filozofija dublje ćemo razumjeti i moći mijenjati elemente svoje nastave, biti spremniji preispitivati teorije, uočavati kontradikcije u njima te razumjeti pretpostavke i koncepte koji su u podlozi odgojno-obrazovnih teorija (Tupas i Pendon, 2016). Tek tada kada osvijestimo svoju odgojno-obrazovnu filozofiju i razloge zbog kojih u nastavi djelujemo na određeni način, možemo napraviti pravu samorefleksiju o sebi kao nastavniku i o svojoj nastavi. Potom, ako uočimo neke nedosljednosti između svojih odgojno-obrazovnih filozofija, uvjerenja koja su im u pozadini i svoje nastavne prakse, možemo početi više promišljati o tome kako da ih uskladimo i unaprijedimo sebe kao nastavnike, a time i svoju nastavu.

\section{KLASIFIKACIJA ODGOJNO-OBRAZOVNIH FILOZOFIJA}

Kako ne postoji ujednačenost u definiranju odgojno-obrazovnih filozofija, tako ne postoji ni slaganje $u$ identifikaciji odgojno-obrazovnih filozofija i njihovoj klasifikaciji. Sadker i Zittleman (2016) te Watson i Coso Strong (2013) identificiraju pet odgojno-obrazovnih filozofija na kontinuumu od onih više usmjerenih na nastavnika: esencijalizam i perenijalizam, do onih više usmjerenih na učenika: progresivizam, socijalni rekonstrukcionizam i egzistencijalizam. Odgojno-obrazovnim filozofijama usmjerenima na nastavnika zajedničko je to što naglašavaju prijenos znanja i vještina sa starijih (i mudrijih) generacija na one mlađe. Nastavnik je taj koji ima zadatak to postići i koji treba posjedovati autoritet kako bi u tome uspio. Odgojno-obrazovnim filozofijama koje su više usmjerene na učenike zajedničko 
je to što u središte odgojno-obrazovnog procesa stavljaju učenike, oslanjaju se na njihovu aktivnost $\mathrm{i}$ iskustva koja donose $\mathrm{u}$ školu, a uloga je nastavnika da podupire razvoj učenika. Tupas i Pendon (2016) gore navedenim odgojno-obrazovnim filozofijama dodaju i biheviorizam. Pozivajući se na Kohlberga i Mayera (1972), Silvernail (1992) dijeli ih na filozofiju tradicionalizma, progresivizma i romanticizma.

Ipak, četiri su odgojno-obrazovne filozofije oko kojih se najviše znanstvenika iz ovoga područja slaže (Gezer, 2018; Ornstein i Hunhins, 2018; Şahan i Terzi, 2015): 1) perenijalizam, 2) esencijalizam, 3) progresivizam i 4) rekonstrukcionizam, tj. socijalni rekonstrukcionizam. Perenijalizam i esencijalizam promatraju se kao tradicionalne (Aybek i Aslan, 2017; Ornstein i Hunhins, 2018; Şahan i Terzi, 2015), tj. moderne (Gezer, 2018) odgojno-obrazovne filozofije, a progresivizam i (socijalni) rekonstrukcionizam kao suvremene (Aybek i Aslan, 2017; Ornstein i Hunhins, 2018; Şahan i Terzi, 2015), tj. postmoderne odgojno-obrazovne filozofije (Gezer, 2018). Svaka od navedenih odgojno-obrazovnih filozofija ima korijen u nekoj filozofiji/nekima od pristupa u filozofiji i u njihovim metafizičkim, epistemološkim i aksiološkim uvjerenjima. Odgojno-obrazovna filozofija perenijalizma oslanja se na realizam, esencijalizam na idealizam i realizam, progresivizam i (socijalni) rekonstrukcionizam na pragmatizam, a (socijalni) rekonstrukcionizam u određenoj mjeri i na egzistencijalizam (Orsntein i Hunkins, 2018).

\section{a) TRADICIONALNE/MODERNE ODGOJNO-OBRAZOVNE FILOZOFIJE - ESENCIJALIZAM I PERENIJALIZAM}

Odgojno-obrazovna filozofija esencijalizma utemeljena je u filozofiji idealizma i realizma (Ornstein i Hunhins, 2018). „Cilj je esencijalizma obrazovanje i odgoj korisne i kompetentne osobe, osposobljavanje pojedinca za ostvarivanje razvitka zajednice, njenih demokratskih vrijednosti i društvene stabilnosti, a temeljno je obrazovanje usmjereno na čitanje, pisanje i računanje“" (Cetinić, 2005, str. 30).

Esencijalizam drži da se čovjek rađa kao tabula rasa i razvija se odgojem i obrazovanjem (Aybek i Aslan, 2017; Terzi i Uyangör, 2017). Naglasak se u obrazovanju stavlja na učenje akumuliranog znanja naše civilizacije, a znanje se stječe tradicionalnim akademskim disciplinama i predmetima - matematika, prirodoznanstveni predmeti, materinski i strani jezik i književnost, koji čine jezgrovni kurikul (Sadker i Zittleman, 2016). Nastavnici koji prihvaćaju ovu odgojno-obrazovnu filozofiju kao cilj postavljaju prenijeti učenicima temeljno znanje akademskih disciplina, tj. znanja i vještine koje su se u prošlosti pokazale korisnima, patriotizam i temeljne vrijednosti kulture te izgraditi čvrst karakter (Gezer, 2018; Ornstein i Hunhins, 2018; Sadker i Zittleman, 2016; Sahan i Terzi, 2015). Za nastavnike koji prihvaćaju ovu odgojno-obrazovnu filozofiju karakteristično je uvjerenje da trebaju obrazovati svako dijete, a naglasak stavljaju na intelektualni razvoj učenika 
i kognitivno područje razvoja, dok su u nastavi više orijentirani na sadržaj predmeta koji poučavaju nego na učenike (Tupas i Pendon, 2016). Također, osim na sadržaju, u nastavi je naglasak na nastavnicima, a ne na učenicima, jer se smatra da nastavnik učenicima treba biti intelektualni i moralni uzor. Nastavnik (kao dobar poznavatelj akademske discipline unutar koje se nalazi predmet koji poučava) jest taj koji određuje što će se i na koji način učiti te se u oblikovanju nastave ne oslanja na interese učenika, a napredovanje učenika vrjednuje njihovim rezultatima na ispitima (Sadker i Zittleman, 2016). Na temelju pregleda literature Gezer (2018) ističe da se u odgojno-obrazovnoj filozofiji esencijalizma naglasak stavlja na odgajanje učenika u skladu s dominantnim vrijednostima kulture kako bi se oni uklopili u društvo. Nastavnici koji prihvaćaju ovu odgojno-obrazovnu filozofiju nastavnika vide u ulozi predstavnika i modela društva koji treba posjedovati autoritet, na nastavi ima dominantnu i aktivnu ulogu, oslanja se isključivo na poučavanje znanja iz knjiga, učenike poučava točnim odgovorima te daje kazne kada je to potrebno. Nastavnici vjeruju kako je uloga učenika da budu pasivni sudionici nastave koji trebaju zapamtiti ono što uče jer najbolje razvijaju svoje sposobnosti učenjem iz knjiga, a također smatraju da se učenici trebaju dosta truditi i svladavati izazove jer je to u podlozi učenja.

Odgojno-obrazovna filozofija perenijalizma utemeljena je u filozofiji realizma (Ornstein i Hunhins, 2018; Terzi i Uyangör, 2017). Nastavnici koji zastupaju ovu odgojno-obrazovnu filozofiju drže da je cilj odgoja i obrazovanja razvoj racionalne misli i discipliniranje uma jer vjeruju da je razum čovjekova najveća snaga (Cetinić, 2005; Sadker i Zittleman, 2016; Terzi i Uyangör, 2017), a to se ostvaruje isključivo preko odgojno-obrazovnih ustanova (Cetinić, 2005). Nastavnici se zato usredotočuju na „velike“ knjige, ideje i koncepte koji su sposobni odoljeti zubu vremena, a esencijalistima zamjeraju što su najviše usredotočeni na to da učenici zapamte veliku količinu činjeničnih informacija (Sadker i Zittleman, 2016). Nastavnici vjeruju da postoje univerzalne i apsolutne istine, a odgoj i obrazovanje trebali bi biti u skladu s njima, stoga bi cilj odgoja i obrazovanja trebao biti odgojiti ljude s jakim i pravim karakterom te raditi na intelektualnome razvoju pojedinaca jer je osnovni i najvažniji dio ljudske prirode čovjekov um (Aybek i Aslan, 2017; Gezer, 2018; Ornstein i Hunhins, 2018; Sadker i Zittleman, 2016; Sahan i Terzi, 2015). Obrazovanje pak promatraju kao mehanizam sortiranja pojedinaca jer se u institucionalnom kontekstu mogu i trebaju prepoznati intelektualno nadarene osobe, a njih je potrebno pripremati za vodstvo, dok bi ostali trebali biti usmjeravani u strukovno obrazovanje (Sadker i Zittleman, 2016). Gezer (2018) sažima glavne odrednice perenijalizma koje se tiču uvjerenja nastavnika: u poučavanju naglasak stavljaju na nepromjenjiva i univerzalna znanja i vrijednosti, učenje i proučavanje klasika, davanje primjera iz stvarnoga života, a najvažnijim smatraju intelektualni razvoj pojedinca. Također, nastavnici smatraju da oni trebaju imati središnje mjesto u nastavi, koriste se metodama dedukcije, poput eksperimenta, promatranja i 
sokratskoga dijaloga, a učenici bi trebali slušati nastavnike i preuzeti odgovornost za svoje učenje. Usto, nastavnici vjeruju da se odgojem i obrazovanjem učenici pripremaju za život i da je zbog toga potrebno školovanjem prenijeti odrednice kulture mlađim generacijama (Ilhan i sur., 2014).

Odgojno-obrazovnim filozofijama perenijalizma i esencijalizma zajedničko je to što su usmjerene na sadržaj i na nastavnika čija je zadaća prenijeti znanje i kulturne vrijednosti učenicima, dok se manje pozornosti pridaje procesu učenja i učenicima, kojima je u nastavi dodijeljena pasivna uloga (Gezer, 2018; Ornstein i Hunhins, 2018; Sadker i Zittleman, 2016; Sahan i Terzi, 2015; Watson i Coso Strong, 2013). Uvjerenja koja su u pozadini ovih odgojno-obrazovnih filozofija uglavnom su već prevladana u suvremenoj pedagogijskoj misli, premda to ne znači da su u potpunosti prevladana i u suvremenoj odgojno-obrazovnoj praksi.

\section{b) SUVREMENE/POSTMODERNE ODGOJNO-OBRAZOVNE FILOZOFIJE - PROGRESIVIZAM I (SOCIJALNI) REKONSTRUKCIONIZAM}

Progresivizam predstavlja prelazak s odgojno-obrazovnih filozofija usmjerenih na nastavnika i sadržaj na one usmjerene na učenika i na proces učenja. Utemeljen je u filozofiji pragmatizma (Ornstein i Hunhins, 2018) i zasnovan na ideji da je samo promjena ono što se nikada ne mijenja (Terzi i Uyangör, 2017). Nastavnici koji prihvaćaju ovu odgojno-obrazovnu filozofiju smatraju kako u stjecanju novoga znanja učenicima pomažu prethodna znanja i iskustva, da je nastavnikova uloga usmjerivati učenike i poticati ih na učenje u stvarnim situacijama (Tupas i Pendon, 2016), da su učenici središte odgoja i obrazovanja te se u poučavanju usmjeruju na njihove potrebe i interese (Cetinić, 2005). Za nastavnike je cilj odgoja i obrazovanja razvoj pojedinaca koji promišljaju o svemu, razvijaju svoj stav i na taj način pridonose društvu (Cetinić, 2005).

Nastavnici koji zastupaju odgojno-obrazovnu filozofiju progresivizma u nastavnom procesu naglasak stavljaju na učenike, potiču ih na izražavanje mišljenja i na dijalog, usmjereni su na individualni rad učenika ili na rad učenika u manjim skupinama, a od njih očekuju i sudjelovanje u donošenju razrednih pravila (Williams, 1996). Odgoj i obrazovanje, unutar ove odgojno-obrazovne filozofije, ne podrazumijevaju samo prijenos znanja i pripremu za život, već su oni i život sami po sebi. Odgoj i obrazovanje trebaju biti usmjereni na interese i potrebe konkretnih učenika, a u učenju bi naglasak trebao biti na rješavanju problema, povezivanju i primjeni naučenoga u stvarnome životu, tj. na aktivnome učenju i praktičnome i primjenjivome znanju (Gezer, 2018; Ornstein i Hunhins, 2018; Sadker i Zittleman, 2016; Sahan i Terzi, 2015; Terzi i Uyangör, 2017). Osim toga, Gezer (2018) navodi kako nastavnici koji prihvaćaju ovu odgojno-obrazovnu filozofiju organiziraju nastavu tako da učenike potiču na razvoj kritičkog mišljenja, a oni vode učenike, planiraju nastavni proces oslanjajući se na interese i potrebe 
učenika, kreiraju demokratsko okruženje za učenje, potiču suradničko učenje i služe se problemskom nastavom u poučavanju.

Druga suvremena/postmoderna odgojno-obrazovna filozofija jest (socijalni) rekonstrukcionizam, a ona je utemeljena u filozofiji pragmatizma i dijelom u filozofiji egzistencijalizma (Ornstein i Hunhins, 2018). U ovoj odgojno-obrazovnoj filozofiji naglasak se stavlja na promišljanje pojedinca (učenika), na razvijanje kritičkog mišljenja te na djelovanje u društvu i za društvo, s ciljem stvaranja novog, boljeg i pravednijeg društva (Aybek i Aslan, 2017). Nastavnici koji prihvaćaju ovu odgojno-obrazovnu filozofiju uvjerenja su da su odgoj i obrazovanje sredstvo uravnoteženja društva i osiguranja idealnog društvenog poretka te provođenja promjena u društvu (Gezer, 2018; Ornstein i Hunhins, 2018; Sadker i Zittleman, 2016; Sahan i Terzi, 2015; Terzi i Uyangör, 2017). U nastavi i nastavnici i učenici imaju aktivnu ulogu, promišljaju o stvarnome svijetu i o problemima s kojima se društvo suočava te osmišljavaju konkretne akcije koje mogu poduzeti za uvođenje promjene, društveno su angažirani i to smatraju najvećom vrijednosti odgoja i obrazovanja. Nastavnici se, u težnji da stvore bolje i novo društvo, vode demokratskim načelima, kao i nastavnici koji prihvaćaju odgojno-obrazovnu filozofiju pragmatizma (Terzi i Uyangör, 2017).

Gezer (2018) na temelju pregleda relevantne literature ističe da nastavnici koji prihvaćaju ovu odgojno-obrazovnu filozofiju stvaraju planove za ostvarenje društvenih reforma i žele uvesti promjene u društvu. Nastavnici, isto tako, kreiraju demokratsku atmosferu u učionici, predstavnici su promjena, naglasak stavljaju na praksu, organiziraju projektnu nastavu, ne koriste se kaznama, osvještavaju učenike o problemima s kojima se čovječanstvo suočava, nastoje im razviti svijest o raznim nepravdama i nejednakostima u društvu. Osim na sadržaje predviđene isključivo nastavnim planom i programom, nastavnici se usmjeruju i na aktualne teme i društvene probleme, poput nezaposlenosti, siromaštva, nejednakosti, rasizma, seksizma, migracija itd., kako bi osvijestili učenike o problemima koji ugrožavaju čovječanstvo i ljudsko dostojanstvo. Nastavnici koji prihvaćaju ovu odgojno-obrazovnu filozofiju smatraju da učenici trebaju biti aktivni sudionici nastavnog procesa, dolaziti do zaključaka tako što raspravljaju o različitim idejama i tezama te stvarati uvjerenja o potrebnim promjenama u društvu i djelovati u skladu s njima. Tupas i Pendon (2016) ističu da nastavnici koji prihvaćaju odgojno-obrazovnu filozofiju (socijalnog) rekonstrukcionizma u nastavi često potiču i usmjeruju učenike na rad u skupinama, vjeruju da iskustvo učenja u skupini mora biti autentično, imati unutarnju vrijednost za učenike i zahtijevati društvene akcije te zbog toga surađuju s lokalnom zajednicom. Nadalje, upućuju na to da nastavnici u ovoj odgojno-obrazovnoj filozofiji imaju ulogu mentora i usmjeruju učenike u pokušajima djelovanja s ciljem uvođenja promjena u društvu. Njihov je zadatak uzeti u obzir akademske i osobne ciljeve učenika te to povezati s nekim problemom u društvu i tako ih uključiti u korisno društveno djelovanje. Nastavnici koji 
zastupaju ovu odgojno-obrazovnu filozofiju često vode dijaloge s učenicima, pomažu im u identificiranju problema, postavljanju hipoteza, pronalaženju podataka, izvlačenju zaključaka i osmišljavanju djelovanja te su usmjereni na provođenje akcijskih istraživanja.

Zajedničko je ovim dvjema odgojno-obrazovnim filozofijama da stavljaju učenika u središte nastavnog procesa, pridaju važnost aktivnosti učenika u nastavi i njihovu kritičkom promišljanju, a predstavnici obiju odgojno-obrazovnih filozofija smatraju da je uloga nastavnika voditi učenike na njihovu putu do spoznaje (Gezer, 2018; Ornstein i Hunhins, 2018; Sadker i Zittleman, 2016; Sahan i Terzi, 2015; Terzi i Uyangör, 2017). Suvremena pedagogijska paradigma pod velikim je utjecajem uvjerenja koja su u pozadini ovih odgojno-obrazovnih filozofija.

\section{ISTRAŽIVANJA O ODGOJNO-OBRAZOVNIM FILOZOFIJAMA}

Istraživanja o odgojno-obrazovnim filozofijama najčešće su usmjerena na identificiranje zastupljenosti određenih odgojno-obrazovnih filozofija na uzorku osnovnoškolskih učitelja, srednjoškolskih nastavnika ili studenata nastavničkih smjerova i na istraživanje odnosa tih filozofija s različitim aspektima djelovanja. Tako je istraživana povezanost odgojno-obrazovnih filozofija s pristupima poučavanju (Watson i Coso Strong, 2013), s pristupima učenju i poučavanju (Şahan i Terzi, 2015), s koncepcijama učenja i poučavanja ${ }^{4}$ (Aslan, 2018; Baş, 2015), s razvijenosti dispozicija kritičkog mišljenja (Aybek i Aslan, 2017), s uvjerenjima nastavnika o samoefikasnosti (Oğuz Er, 2020), sa stavovima prema poučavanju usmjerenome na učenika (Williams, 1996) i sa stavovima prema multikulturalnom odgoju i obrazovanju (Gezer, 2018).

Cetinić (2005) provela je istraživanje na uzorku osnovnoškolskih i srednjoškolskih nastavnika u RH. Rezultati istraživanja pokazali su da su nastavnici najskloniji odgojno-obrazovnoj filozofiji progresivizma, zatim biheviorizma i perenijalizma, a najmanje odgojno-obrazovnim filozofijama esencijalizma i egzistencijalizma. Iako su sudionici bili naklonjeniji suvremenoj odgojno-obrazovnoj filozofiji, progresivizmu, ipak je velik broj njih iskazao slaganje i s tradicionalnim odgojno-obrazovnim filozofijama. Istraživanje Tupasa i Pendona (2016) provedeno na uzorku studenata nastavničkog smjera također je pokazalo da studenti znatno više prihvaćaju suvremene odgojno-obrazovne filozofije (progresivizam, egzistencijalizam i rekonstrukcionizam), a manje one tradicionalne. Sličan je rezultat

\footnotetext{
${ }^{4}$ Koncepcije učenja i poučavanja odnose se na aktivnosti, metode i načine rada kojima se nastavnici koriste u organiziranju nastavnog okruženja (Chan i Elliot, 2004, prema Aslan 2018), a danas prepoznajemo dvije dominantne koncepcije, tradicionalnu i konstruktivističku (Baş, 2015). Slično tome Kember i Kwan (2002) prepoznaju dvije šire koncepcije, sa po dvije potkategorije: a) poučavanje kao transmisija znanja - poučavanje kao prijenos informacija i poučavanje kao olakšavanje razumijevanja studentima; b) poučavanje kao podupiranje učenja - poučavanje kao zadovoljavanje potreba učenja studenata i poučavanje kao podupiranje studenata da postanu neovisni u učenju.
} 
dobio i Silvernail (1992) koji je ispitivao odgojno-obrazovne filozofije srednjoškolskih nastavnika. Nastavnici su se najviše slagali s odgojno-obrazovnom filozofijom progresivizma, a najmanje s onom romanticizma, iako su se sudionici istraživanja generalno slagali sa svim trima odgojno-obrazovnim filozofijama te se nijedna od njih nije pokazala dominantnom.

Şahan i Terzi (2015) proveli su istraživanje među budućim učiteljima kako bi ispitali povezanost između njihovih odgojno-obrazovnih filozofija i njihovih pristupa učenju i poučavanju. Ispitanici su, slično kao i u prethodnim istraživanjima, bili najnaklonjeniji progresivizmu, potom rekonstrukcionizmu i perenijalizmu, a najmanje esencijalizmu. U pogledu pristupa učenju i poučavanju ispitanici su znatno naklonjeniji konstruktivizmu negoli tradicionalnom pristupu. $U$ istraživanju je utvrđena pozitivna korelacija u prihvaćanju perenijalizma i esencijalizma s tradicionalnim pristupima učenju i poučavanju te u prihvaćanju progresivizma $\mathrm{i}$ rekonstrukcionizma s konstruktivističkim pristupom učenju i poučavanju.

Osim što su odgojno-obrazovne filozofije povezane s pristupima učenju i poučavanju, one su povezane i s koncepcijama učenja i poučavanja. Odgojnoobrazovne filozofije progresivizma, rekonstrukcionizma i egzistencijalizma statistički su značajno povezane sa suvremenom konstruktivističkom koncepcijom učenja i poučavanja, a odgojno-obrazovne filozofije perenijalizma i esencijalizma statistički su značajno povezane s tradicionalnom koncepcijom učenja i poučavanja (Baş, 2015). Autor zaključuje da odgojno-obrazovna filozofija koja je dominantno izražena kod pojedinog nastavnika ima značajnu, ako ne i ključnu ulogu u razvoju njegovih koncepcija učenja i poučavanja. Iako je kurikul u Turskoj konstruktivistički orijentiran, Baş ističe kako nastavnici i nadalje više prihvaćaju perenijalistička i esencijalistička uvjerenja te su i njihova djelovanja više u skladu $s$ tradicionalnom koncepcijom učenja i poučavanja.

Williams (1996) ispitivala je povezanost između odgojno-obrazovnih filozofija nastavnika i njihovih stavova prema poučavanju usmjerenom na učenike. Rezultati su pokazali statistički značajnu, ali slabu pozitivnu korelaciju između odgojno-obrazovne filozofije progresivizma i stavova nastavnika prema poučavanju usmjerenom na učenike, no pokazali su i slabu pozitivnu korelaciju između tradicionalne odgojno-obrazovne filozofije i stavova nastavnika prema poučavanju usmjerenom na učenike. Autorica zaključuje da nastavnici u navedenom istraživanju generalno imaju pozitivne stavove prema poučavanju usmjerenom na učenike, ali podjednako naginju objema odgojno-obrazovnim filozofijama. Dobivene rezultate objašnjava time što ispitanici općenito naginju srednjim kategorijama na ljestvicama procjene, a koje im u provedenome istraživanju nisu bile ponuđene. Preporuka koju daje za odgojno-obrazovnu praksu jest poučavanje budućih nastavnika o odgojno-obrazovnim filozofijama i njihovu utjecaju na nastavnu praksu u sklopu kolegija na nastavničkim fakultetima, ali i razvijanje programa za usavršavanje u ovome području za nastavnike koji su već zaposleni. Predlaže se da u 
programima usavršavanja naglasak bude na tehnikama samoprocjene, na promišljanju i razgovaranju o mogućim razlozima razlika između uvjerenja nastavnika i njihove prakse te na uočavanju tih razlika.

Gezer (2018) ispitivala je povezanost odgojno-obrazovnih filozofija budućih nastavnika s njihovim stavovima prema multikulturalnom obrazovanju. Moderne odgojno-obrazovne filozofije (esencijalizam i perenijalizam) bile su statistički značajno, ali negativno povezane sa stavovima o multikulturalnom obrazovanju, dok su postmoderne odgojno-obrazovne filozofije (progresivizam i rekonstrukcionizam) bile statistički značajno pozitivno povezane sa stavovima o multikulturalnom obrazovanju. Autorica zaključuje da takav rezultat ne čudi imamo li u vidu uvjerenja koja su u pozadini navedenih odgojno-obrazovnih filozofija. Ona preporučuje da se buduća istraživanja usmjere na kvalitativnu metodologiju kako bi se dobio dublji i obuhvatniji uvid u istraživački problem.

U istraživanju povezanosti odgojno-obrazovnih filozofija studenata nastavničkog smjera s razvijenošću kritičkoga mišljenja (Aybek i Aslan, 2017) dobiven je rezultat da je razvijenost kritičkog mišljenja umjereno povezana sa suvremenim odgojno-obrazovnim filozofijama, progresivizmom i rekonstrukcionizmom, no nije povezana s tradicionalnim odgojno-obrazovnim filozofijama, perenijalizmom i esencijalizmom. Watson i Coso Strong (2013) u istraživanju provedenome među studentima nastavničkog smjera došle su do zaključka da su na njihovu uzorku ispitanika gotovo podjednako zastupljene odgojno-obrazovne filozofije esencijalizma i progresivizma. U istraživanju su ispitivale i koje su odgojno-obrazovne filozofije najzastupljenije u nastavi koju ispitani studenti pohađaju. Rezultati istraživanja pokazali su da je ta nastava uglavnom tradicionalna, s obilježjima esencijalističke i perenijalističke odgojno-obrazovne filozofije, što se odražava i na odgojno-obrazovne filozofije koje prihvaćaju studenti. Autorice također zaključuju da je u kolegije koji studente pripremaju za rad u nastavi potrebno uključiti teme o odgojno-obrazovnim filozofijama i njihovim implikacijama na učenje i poučavanje.

Pregledom istraživanja uočavamo da na odgojno-obrazovne filozofije utječu sljedeće sociodemografske varijable: predmetno područje nastavnika (Cetinić, 2005; Oğuz Er, 2020; Şahan i Terzi, 2015; Silvernail, 1992; Terzi i Uyangör, 2017; Watson i Coso Strong, 2013), spol (Oğuz Er, 2020; Şahan i Terzi, 2015; Silvernail, 1992; Terzi i Uyangör, 2017), radni staž (Cetinić, 2005), prethodno iskustvo (Watson i Coso Strong, 2013), vrsta škole u kojoj su nastavnici zaposleni - osnovna škola, gimnazija ili srednja strukovna škola (Cetinić, 2005), stručna sprema (Cetinić, 2005) i temeljno osposobljavanje za nastavničku profesiju (Watson i Coso Strong, 2013).

Iz navedenih istraživanja moguće je zaključiti da su se sudionici istraživanja uglavnom najviše slagali s odgojno-obrazovnom filozofijom progresivizma, što ne čudi jer i suvremene paradigme u pedagogiji preuzimaju dosta odrednica te odgojno-obrazovne filozofije koja danas predstavlja dominantan diskurs u odgoju 
i obrazovanju. Ipak, sudionici istraživanja u nekim su istraživanjima pokazali slaganje i s odgojno-obrazovnim filozofijama koje se klasificiraju kao tradicionalne/ moderne što autori objašnjavaju iskustvom koje su ispitanici stekli ili ga još stječu kao studenti. Teme povezane s odgojno-obrazovnim filozofijama bitne su, no donekle zanemarene, te se ističe potreba uključivanja takvih tema u kolegije na nastavničkim studijima kako bi nastavnici postali svjesni uvjerenja koja su u pozadini njihovih promišljanja o pedagogijskim pitanjima, a koja ujedno utječu i na njihova djelovanja i to najčešće na nesvjesnoj i implicitnoj razini. Zato je potrebno osvijestiti ih, promišljati i raspravljati o njima te provoditi refleksiju o vlastitom radu kako bismo uistinu mogli raditi na unaprjeđenju nastavnog procesa.

\section{ZAKLJUČAK}

Nastavnici su temelj kvalitete svakog odgojno-obrazovnog sustava. Bez kvalitetnih, predanih i motiviranih odgojno-obrazovnih djelatnika koji promišljaju o svojem radu i teže usavršavanju i daljnjem napredovanju nema ni uspješnog odgojno-obrazovnog sustava. Iako nastavnici uglavnom nisu svjesni svojih odgojno-obrazovnih filozofija, one su ipak povezane s njihovim odgojno-obrazovnim djelovanjima u nastavnome procesu te se na njihovu odgojno-obrazovnu praksu najčešće implicitno odražavaju. Upravo je zbog toga potrebno više pisati i govoriti o odgojno-obrazovnim filozofijama, a s nastavnicima raditi na njihovu osvještavanju.

Iako se na međunarodnoj razini podosta pisalo o odgojno-obrazovnim filozofijama, u domaćoj je literaturi to poprilično zanemarena tema, s iznimkom jednoga magistarskog rada (Cetinić, 2005) kojim su se ispitale odgojno-obrazovne filozofije nastavnika u RH. Ovim se radom zato željelo pridonijeti razmatranju navedenoga konstrukta i u nacionalnim okvirima. Premda postoji dosta strane literature o odgojno-obrazovnim filozofijama, a od 80-ih godina prošlog stoljeća o njima se intenzivno piše, ipak u mnogim člancima nedostaje eksplicitna definicija konstrukta.

Cilj ovoga rada bio je dati pregled literature o odgojno-obrazovnim filozofijama nastavnika i prilog određenju tog konstrukta te uputiti na važnost njegova istraživanja unutar pedagogije i povezati odgojno-obrazovne filozofije nastavnika s njihovim djelovanjem u odgojno-obrazovnoj praksi. Na temelju pregleda dostupne literature u radu je stoga ponuđena definicija koja glasi: odgojno-obrazovne filozofije predstavljaju poimanja nastavnika o pitanjima koja su usko vezana za odgoj i obrazovanje, a zasnovana su na nastavnikovim metafizičkim, epistemološkim i aksiološkim uvjerenjima. S obzirom na razlike u tim uvjerenjima moguće je identificirati više odgojno-obrazovnih filozofija. Premda se svi autori međusobno ne slažu u pogledu njihova identificiranja, možemo zaključiti da su danas njih četiri, oko kojih postoji slaganje, ipak dominantne, a to su perenijalizam i esencijalizam, kao tradicionalne/moderne odgojno-obrazovne filozofije, te progresivizam i (socijalni) rekonstrukcionizam kao suvremene/postmoderne odgojno-obrazovne 
filozofije. Na stupanj prihvaćanja pojedine odgojno-obrazovne filozofije utječu različite sociodemografske karakteristike nastavnika, a istraživanja su potvrdila i povezanost odgojno-obrazovnih filozofija s različitim aspektima djelovanja nastavnika. Upravo je zbog toga dodatno naglašena važnost istraživanja i produbljivanja spoznaja o odgojno-obrazovnim filozofijama te je istaknut prijedlog za uključivanjem ove teme u kolegije iz područja pedagogije na nastavničkim studijima u RH i za organiziranjem usavršavanja za nastavnike koji već rade u školama. Cilj takvih programa bio bi osvještavanje odgojno-obrazovnih filozofija nastavnika i refleksija na njihovu odgojno-obrazovnu praksu te promišljanje o mogućnostima njezina unaprjeđenja. Preporuke za daljnja istraživanja ovoga područja jesu da se primjenom kvantitativne, ali i kvalitativne metodologije dublje i obuhvatnije istraži konstrukt odgojno-obrazovnih filozofija te njegova povezanost s još neistraženim aspektima djelovanja nastavnika.

\section{LITERATURA}

1. Åkerlind, G. S. (2008). A phenomenographic approach to developing academics> understanding of the nature of teaching and learning. Teaching in Higer Education, 13(6), 633-644. https://doi.org/10.1080/13562510802452350

2. Åkerlind, G. S.(2004). A new dimension to understanding university teaching. Teaching in Higher Education, 9(3), 363-375. https://doi.org/10.1080/1356251042000216679

3. Aslan, S. (2018). Investigating the relation between educational philosophies adopted by prospective teachers and their teaching-learning conceptions. Pegem Eğitim ve Öğretim Dergisi, 8(2), 307-326.http://dx.doi.org/10.14527/pegegog.2018.013

4. Aybek, B. i Aslan, S. (2017). The Relationship between Prospective Teachers' Critical Thinking Dispositions and Their Educational Philosophies. Universal Journal of Educational Research, 5(4), 544-550. DOI: 10.13189/ujer.2017.050403

5. Baş, G. (2015). Correlation Between Teachers' Philosophy of Education Beliefs and Their Teaching-Learning Conceptions. Education and Science, 40(182), 111-126. DOI: 10.15390/EB.2015.4811

6. Beatty, J. E., Leigh, J. S. A. i Dean, K. L. (2009). Philosophy Rediscovered. Exploring the Connections Between Teaching Philosophies, Educational Philosophies, and Philosophy. Journal of Management Education, 33(1), 99-114. https://doi. org $/ 10.1177 / 1052562907310557$

7. Cetinić, G. (2005). Struktura odgojno-obrazovnih filozofija učitelja u Republici Hrvatskoj [magistarski rad, Sveučilište u Rijeci, Filozofski fakultet u Rijeci].

8. Dunkin, M. J. (2002). Novice and Award-Winning Teachers' Concepts and Beliefs About Teaching in Higher Education. U N. Hativa i P. Goodyear (ur.), Teacher Thinking, Beliefs and Knowledge in Higher Education (str. 41-57). Kluwer.

9. Entwistle, N. i Walker, P. (2002). Strategic alertness and Expanded Awareness Within Sophisticated Conceptions of Teaching. U N. Hativa i P. Goodyear (ur.), Teacher Thinking, Beliefs and Knowledge in Higher Education (str. 15-39). Kluwer. 
10. Gezer, M. (2018). An analysis of correlations between prospective teachers' philosophy of education and their attitudes towards multicultural education. Cogent Education, 5(1), 1475094. https://doi.org/10.1080/2331186X.2018.1475094

11. Hativa, N. i Goodyear, P. (2002). Research on Teacher Thinking, Beliefs and Knowledge in Higher Education: Foundations, Status and Prospects. U N. Hativa i P. Goodyear (ur.), Teacher Thinking, Beliefs and Knowledge in Higher Education (str. 335-359). Kluwer.

12. Ilhan, M., Çetin, B. iArslan, S. (2014). Prospective Teachers' Individual Innovativeness and Their Adopted Philosophies of Education. US-China Education Review B, 4(4), 223-244. https://www.academia.edu/24315271/Prospective_Teachers_Individual_ Innovativeness_and_Their_Adopted_Philosophies_of_Education

13. Kember, D. i Kwan, K. (2002). Lecturers' Approaches to Teaching and Their Relationship to Conceptions od Good Teaching. U N. Hativa i P. Goodyear (ur.), Teacher Thinking, Beliefs and Knowledge in Higher Education (str. 219-239). Kluwer.

14. Martin, E., Prosser, M., Trigwell, K., Ramsden, P. i Benjamin, J. (2002). What University Teachers Teach and How They Teach it. U N. Hativa i P. Goodyear (ur.), Teacher Thinking, Beliefs and Knowledge in Higher Education (str. 103-126). Kluwer.

15. Mcalpine, L. i Weston, C. (2002). Reflection: Issues Related to Improving Professors' Teaching and Students' Learning. U N. Hativa i P. Goodyear (ur.), Teacher Thinking, Beliefs and Knowledge in Higher Education (str. 59-78). Kluwer.

16. Ministarstvo znanosti i obrazovanja (2019). Predmetni kurikulumi. Republika Hrvatska, Ministarstvo znanosti i obrazovanja. https://mzo.gov.hr/istaknute-teme/ odgoj-i-obrazovanje/nacionalni-kurikulum/predmetni-kurikulumi/539

17. Nespor, J. (1987). The role of beliefs in the practice of teaching. Journal of Curriculum Studies, 19(4), 317-328. https://doi.org/10.1080/0022027870190403

18. Norton, L., Richardson, J.T.E., Hartley, J., Newstead, S. i Mayes, J. (2005). Teachers' beliefs and intentions concerning teaching in higher education. Higher Education, 50, 537-571. https://link.springer.com/article/10.1007/s10734-004-6363-z

19. Oğuz Er, K. (2020). The relationship between teacher self-efficacy beliefs and educational beliefs of pre-service teachers. Educational Research and Reviews, 15(1), 8-18. https://eric.ed.gov/?id=EJ1238407

20. Ornstein, A. C. i Hunkins, F. P. (2018). Curriculum: Foundations, Principles and Issues (Seventh Edition, Global Edition). Pearson.

21. Pajares, M. F. (1992). Teachers' Beliefs and Educational Research: Cleaning Up a Messy Construct. Review of Educational Research, 62(3), 307-332. https://doi. org/10.3102/00346543062003307

22. Pratt, D. D., Smulders, D. i sur. (2016). Five Perspectives on Teaching: Mapping a Plurality of the Good-Second Edition. Krieger Publishing Company.

23. Rissanen, I., Kuusisto, E., Hanhimäki i Tirr, K. (2016). Teachers' Implicit Meaning Systems and Their Implications for Pedagogical Thinking and Practise: A Case Study from Finland. Scandinavian Journal of Educational Research. DOI: 10.1080/00313831.2016.1258667. 
$\underline{\text { S. Kunac, Odgojno-obrazovne filozofije - ključ razumijevanja uloge nastavnikovih... }}$

24. Sadker, D. M. i Zittleman, K. R. (2016). Teachers, schools, and society: a brief introduction to education, fourth edition. McGraw-Hill Education.

25. Şahan, H. H. i Terzi, A. R. (2015). Analyzing the relationship between prospective teachers' educational philosophies and their teaching-learning approaches. Educational Research and Reviews, 10(8), 1267-1275. https://eric.ed.gov/?id=EJ1063693

26. Silvernali, D. L. (1992). The Educational Philosophies of Secondary School Teachers. The High School Journal, 75(3), 162-167. https://www.jstor.org/stable/40364841

27. Skott, J. (2015). The Promises, Problems, And Prospects of Research on Teachers'Beliefs. U G. Five i M. G. Gill (ur.), International Handbook of Research on Teachers'Beliefs (str. 13-30). Routledge.

28. Taylor, E. W., Dirkx, J. i Pratt, D. D. (2001). Personal Pedagogical Systems: Core Beliefs, Foundational Knowledge, and Informal Theories of Teaching. Adult Education Research Conference. http://newprairiepress.org/cgi/viewcontent. cgi?article $=2346 \&$ context $=$ aerc

29. Terzi, A. R. i Uyangör, N. (2017). An Analysis of the Relationship between Scientific Epistemological Beliefs and Educational Philosophies: A Research on Formation Teacher Candidates. Universal Journal of Educational Research, 5(12), 2171-2177. DOI:10.13189/UJER.2017.051206

30. Tupas, J. B. i Pendon, G. P. (2016). Prevailing Educational Philosophies among Pre-Service Teachers. IRA International Journal of Education and Multidisciplinary Studies, 3(3), 446-461. http://dx.doi.org/10.21013/jems.v3.n3.p16

31. Udruga za promicanje filozofije Filozofija.org. (b.d.) Rječnik filozofskih pojmova. https://www.filozofija.org/rjecnik-filozofskih-pojmova/

32. Watson, M. K. i Coso Strong, A. (2013). Examining graduate students' philosophies of education: An exploratory study. U ASEE Annual Conference and Exposition, Conference Proceedings. DOI:10.18260/1-2--19570

33. Williams, P. A. (1996). Relationship Between Educational Philosophies and Attitudes Toward Learner-centered Instruction. Outstanding Student Research Award of the Georgia Educational Research Association. https://files.eric.ed.gov/fulltext/ ED406377.pdf 